\title{
KAJIAN EKONOMI RUMAHTANGGA PETANI PADI DI KABUPATEN KAMPAR PROVINSI RIAU
}

\author{
Ayu Andria, Elinur, dan Jumatri \\ Jurusan Agribisnis, Fakultas Pertanian, Universitas Riau, Pekanbaru, Indonesia \\ Ayu_andira79@yahoo.com
}

\begin{abstract}
Abstrak
Kajian ekonomi rumahtangga petani meliputi pembahasan tentang rumahtangga petani dari aspek produksi dan konsumsi yang dilakukan secara simultan. Penelitian ini bertujuan untuk menganalisis faktor dominan yang mempengaruhi keputusan ekonomi rumahtangga petani padi. Penelitian menggunakan metode survey untuk mendapatkan gambaran prilaku rumahtangga petani padi. Metode penarikan sampel dengan metode multi stage purposive sampling dengan jumlah sampel sebanyak 60 orang yang berasal dari Kecamatan Bangkinang, Kecamatan Kampar dan Kecamatan Tambang. Jenis data yang dikumpulkan adalah data cross section tahun 2017. Analisis penelitian ini adalah analisis ekonometrika persamaan simultan.

Hasil penelitian menunjukkan bahwa produksi padi signifikan dipengaruhi oleh luas panen dan total tenaga kerja dalam usahatani. Alokasi waktu kerja petani padi dalam usahatani dipengaruhi oleh pendapatan dalam usahatani padi dan angkatan kerja petani, penggunaan tenaga kerja luar rumahtangga petani dipengaruhi oleh pendapatan petani dalam usaha tani, pengalaman kerja petani dan angkatan kerja petani. Alokasi waktu kerja rumahtangga diluar usahatani padi dipengaruhi oleh pendapatan petani diluar usahatani padi dan angkatan kerja petani. Pendapatan rumahtangga petani padi diluar usahatani dipengaruhi oleh curahan kerja petani diluar usaha tani dan curahan kerja petani dalam usahatani. Pengeluaran konsumsi pangan rumahtangga petani padi dipengaruhi oleh pendapatan total petani, jumlah anggota keluarga petani dan investasi pendidikan. Investasi pendidikan rumahtangga petani padi dipengaruhi oleh pendapatan total petani, jumlah anak sekolah dan konsumsi pangan petani. Investasi dalam usaha tani dipengaruhi oleh pendapatan total petani, luas panen dan investasi pendidikan petani. Pengeluaran rekreasi rumahtangga petani dipengaruhi oleh pendapatan total petani, konsumsi pangan petani, investasi pendidikan dan pengeluaran kesehatan. Tabungan rumahtangga petani dipengaruhi oleh pendapatan total petani, konsumsi pangan petani, konsumsi non pangan petani, pengeluaran kesehatan dan investasi pendidikan.
\end{abstract}

\section{Keywords: Ekonomi Rumahtangga Petani, Produksi, Pendapatan, Pengeluaran Rumahtangga Petani}

\section{PENDAHULUAN}

Peran pertanian dalam perekonomian nasional sebagai penyedia bahan pangan bagi penduduk indonesia yang jumlahnya semakin hari semakin meningkat sehingga untuk mengantisipasi terjadinya kerawanan pangan maka

99 Kajian Ekonomi Rumahtangga Petani Padi Di Kabupaten Kampar Provinsi Riau 
pemerintah menggalakkan program ketahanan pangan diantaranya adalah operasi khusus PAJALE (Padi, Jagung, Kedelai).

Kegiatan ekonomi rumahtangga petani meliputi kegiatan produksi dan konsumsi secara simultan. Rumahtangga sebagai konsumen bertujuan memaksimumkan utilitasnya, sedangkan sebagai produsen untuk memaksimumkan keuntungannya. Rumahtangga ini dihadapkan oleh berbagai keterbatasan sumberdaya, sehingga mereka mempunyai pilihan untuk mengalokasikan anggaran untuk produksi dan pengeluaran konsumsi rumahtangganya.

Dalam mencapai tujuan yang diharapkan, rumahtangga sebagai konsumen maupun produsen harus mampu membuat pilihan dan mengambil keputusan yang tepat dalam melakukan aktivitas ekonominya. Aktivitas ekonomi rumahtangga petani meliputi aktivitas produksi dan kunsumsi yang saling berkaitan. Keputusan rumahtangga petani dalam berproduksi akan ditentukan alokasi waktu kerja rumahtangga petani didalam usahatani. Alokasi waktu kerja rumahangga petani akan menentukan pendapatan rumahtangga petani. Pendapatan rumahtangga petani akan mempengeruhi pengeluaran rumahtangga yang meliputi pengeluaran pangan dan non pangan. Pengeluaran pangan dan non pangan akan menentukan tingkat kesejahteraan rumahtangga petani.

Berdasarkan uraian tersebut, permasalahan penelitian ini adalah bagaimana karakteristik rumahtangga petani padi dan faktor dominan apasaja yang mempengaruhi keputusan ekonomi rumahtangga petani padi.

\section{METODE PENELITIAN}

Penelitian menggunakan metode survey untuk mendapatkan gambaran prilaku rumahtangga petani padi. Pelaksanaan penelitian ini selama 6 bulan mulai bulan Juli sampai dengan Desember 2017. Lokasi penelitian di Kecamatan Bangkinang, Kecamatan Kampar dan Kecamatan Tambang. Penetapan lokasi penelitian berdasarkan Kecamatan yang Luas Panen tinggi, Luas Panen menengah dan Luas Panen paling kecil.

Metode penarikan sampel adalah metode multi stage random sampling yang diambil dari Kecamatan Bangkinang, Kecamatan Kampar dan Kecamatan Tambang. Jumlah sampel yang diambil sebanyak 60 rumahtangga petani padi. Jenis data yang dikumpulkan adalah data cross section (kerat lintang) tahun 2017.

100 Kajian Ekonomi Rumahtangga Petani Padi Di Kabupaten Kampar Provinsi Riau 
Data tersebut diperoleh dari wawancara langsung dengan responden, yaitu rumahtangga petani padi dengan menggunakan kuesioner yang telah dipersiapkan.

Analisis data penelitian ini adalah analisis ekonometrika persamaan simultan dilakukan untuk menjawab tujuan penelitian. Analisis ekonometrika persamaan simultan memiliki prosedur, antara lain adalah spesifikasi model ekonomi rumahtangga petani padi sawah, identifikasi model dan estimasi model. Pertama, Spesifikasi model yang terdiri dari persamaan-persamaan yang saling berhubungan yang dikelompokkan ke dalam empat blok, yaitu blok: produksi gabah, alokasi waktu tenaga kerja yang terdiri dalam dan luar usahatani serta penggunaan tenaga kerja luar keluarga, pendapatan dan pengeluaran rumahtangga petani. Keempat blok persamaan tersebut saling berhubungan membentuk persamaan sistem. Spesifikasi model ekonomi rumahtangga petani padi sawah disajikan pada persamaan di bawah ini.

Persamaan produksi padi dirumuskan sebagai berikut:

1. $\mathrm{Q}_{\mathrm{i}}=\mathrm{a}_{0}+\mathrm{a}_{1} \mathrm{LP}_{\mathrm{i}}+\mathrm{a}_{2} \mathrm{TTKU}_{\mathrm{i}}+\mathrm{a}_{3} \mathrm{BSP}+\mathrm{U}_{1 \mathrm{i}}$ dimana:

$\mathrm{Q}_{\mathrm{i}} \quad=$ produksi padi/Gabah (kg/luas panen/tahun)

$\mathrm{LP}_{\mathrm{i}} \quad=$ luas panen $(\mathrm{Ha} / \mathrm{tahun})$

TTKU $_{\mathrm{i}} \quad=$ total tenaga kerja usahtani padi (HOK/tahun)

$\mathrm{BSP}_{\mathrm{i}} \quad=$ biaya sarana produksi (rupiah/tahun)

Tanda parameter dugaan yang diharapkan:

$$
a_{1}, a_{2}, a_{3}>0
$$

2. $\mathrm{CKPD}_{\mathrm{i}}=\mathrm{b}_{0}+\mathrm{b}_{1} \mathrm{PPDU}_{\mathrm{i}}+\mathrm{b}_{2} \mathrm{AKP}_{\mathrm{i}}+\mathrm{U}_{2 \mathrm{i}}$ dimana:

$\mathrm{CKPD}_{\mathrm{i}}=$ curahan kerja rumahtangga petani padi dalam usahatani (HOK/tahun)

$\mathrm{AKP}_{\mathrm{i}}=$ angkatan kerja rumahtangga petani padi (orang)

Tanda parameter dugaan yang diharapkan:

$\mathrm{b}_{1}, \mathrm{~b}_{2}>0$,

3. $\mathrm{TKLP}_{\mathrm{i}}=\mathrm{c}_{0}+\mathrm{c}_{1} \mathrm{PPDU}_{\mathrm{i}}+\mathrm{c}_{2} \mathrm{PKP}_{\mathrm{i}}+\mathrm{c}_{3} \mathrm{AKP}_{\mathrm{i}}+\mathrm{U}_{3 \mathrm{i}}$ dimana:

TKLP $_{\mathrm{i}} \quad=$ tenaga kerja luar rumahtangga petani padi $(\mathrm{HOK} /$ tahun$)$

$\mathrm{PPDU}_{\mathrm{i}}=$ pendapatan rumahtangga petani dalam usaha (rupiah/tahun)

$\mathrm{PKP}_{\mathrm{i}} \quad=$ pengalaman kerja petani (tahun)

$\mathrm{AKP}_{\mathrm{i}} \quad=$ angkatan kerja rumahtangga petani (orang)

Tanda parameter dugaan yang diharapkan:

$$
\mathrm{c}_{1}, \mathrm{c}_{2}, \mathrm{c}_{3}>0
$$

4. $\mathrm{CKPL}_{\mathrm{i}}=\mathrm{d}_{0}+\mathrm{d}_{1} \mathrm{PPLU}_{\mathrm{i}}+\mathrm{d}_{2} \mathrm{AKP}_{\mathrm{i}}+\mathrm{U} 4_{\mathrm{i}}$ dimana:

$\mathrm{CKPL}_{\mathrm{i}}=$ curahan kerja rumahtangga petani di luar usaha (HOK/tahun)

$\mathrm{PPLU}_{\mathrm{i}}=$ pendapatan rumahtangga petani di luar usaha (rupiah/tahun)

$\mathrm{AKP}_{\mathrm{i}}=$ angkatan kerja rumahtangga petani (orang)

101 Kajian Ekonomi Rumahtangga Petani Padi Di Kabupaten Kampar Provinsi Riau 
Tanda parameter dugaan yang diharapkan:

$d_{1}, d_{2}>0$

5.TTKU $\mathrm{T}_{\mathrm{i}}=\mathrm{CKPD}_{\mathrm{i}}+\mathrm{TKLP}_{\mathrm{i}}$

6. $\mathrm{TCKP}_{\mathrm{i}}=\mathrm{CKPD}_{\mathrm{i}}+\mathrm{CKPL}_{\mathrm{i}}$

dimana:

$\mathrm{TCKP}_{\mathrm{i}}=$ total curahan kerja rumahtangga petani (HOK/tahun $)$

TTKU $=$ total tenaga kerja usaha tani padi (HOK/tahun)

7. $\mathrm{PPDU}_{\mathrm{i}}=\left(\mathrm{HB}_{\mathrm{i}}^{*} \mathrm{Q}_{\mathrm{i}}\right)+\mathrm{BSP}_{\mathrm{i}}-\mathrm{TBU}_{\mathrm{i}}$

dimana:

$\mathrm{HB}_{\mathrm{i}}=$ harga gabah (rupiah/kg)

$\mathrm{BSP}_{\mathrm{i}}=$ bantuan sarana produksi (rupiah/tahun)

$\mathrm{TBU}_{\mathrm{i}}=$ total biaya usaha padi (rupiah/tahun)

8. $\mathrm{TBU}_{\mathrm{i}}=\mathrm{UG}_{\mathrm{i}}+\mathrm{BSP}_{\mathrm{i}}$

dimana:

$\mathrm{UG}_{\mathrm{i}}=$ upah/gaji (rupiah)

$\mathrm{BSP}_{\mathrm{i}}=$ biaya sarana produksi (rupiah/tahun)

$\operatorname{PPLU}_{\mathrm{i}}=\mathrm{e}_{0}+\mathrm{e}_{1} \mathrm{CKPL}_{\mathrm{i}}+\mathrm{e}_{2} \mathrm{CKPD}_{\mathrm{i}}+\mathrm{e}_{3} \mathrm{UP}_{\mathrm{i}}+\mathrm{U}_{4 \mathrm{i}}$

dimana:

$\mathrm{CKPL}_{\mathrm{i}}=$ curahan kerja rumahtangga petani di luar usahatani (HOK/tahun)

$\mathrm{CKPD}_{\mathrm{i}}=$ curahan kerja rumahtangga petani di dalam usahatani $(\mathrm{HOK} / \mathrm{tahun})$

$\mathrm{UP}_{\mathrm{i}} \quad=$ umur petani (tahun)

Tanda parameter dugaan yang diharapkan:

$\mathrm{e}_{1}>0, \mathrm{e}_{2}<0$ dan $\mathrm{e}_{3} \neq 0$

9. $\mathrm{PTP}_{\mathrm{i}}=\mathrm{PPDU}_{\mathrm{i}}+\mathrm{PPLU}_{\mathrm{i}}$

dimana:

PTP = pendapatan total rumahtangga petani (rupiah/tahun)

10. $\mathrm{KPP}_{\mathrm{i}}=\mathrm{f}_{0}+\mathrm{f}_{1} \mathrm{PTP}_{\mathrm{i}}+\mathrm{f}_{2} \mathrm{JANP}_{\mathrm{i}}+\mathrm{f}_{3} \mathrm{IEP}_{\mathrm{i}}+\mathrm{U}_{6 \mathrm{i}}$

$\mathrm{KNPP}_{\mathrm{i}}=\mathrm{g}_{0}+\mathrm{g}_{1} \mathrm{PTP}_{\mathrm{i}}+\mathrm{g}_{2} \mathrm{IEP}_{\mathrm{i}}+\mathrm{g}_{3} \mathrm{JANP}_{\mathrm{i}}+\mathrm{U}_{7 \mathrm{i}}$

dimana:

$\mathrm{KPP}_{\mathrm{i}}=$ konsumsi pangan rumahtangga petani padi (rupiah/tahun)

$\mathrm{KNPP}_{\mathrm{i}}=$ konsumsi non pangan rumahtangga petani padi (rupiah/tahun)

JANP $_{i}=$ jumlah anggota keluarga rumahtangga petani padi (orang)

$\mathrm{IEP}_{\mathrm{i}} \quad=$ investasi pendidikan rumahtangga petani padi (rupiah/tahun)

Tanda parameter dugaan yang diharapkan:

$\mathrm{f}_{1}, \mathrm{f}_{2}, \mathrm{~g}_{1}, \mathrm{~g}_{3}>0$ dan $\mathrm{f}_{3}, \mathrm{~g}_{2}<0$

$\mathrm{KTP}_{\mathrm{i}}=\mathrm{KPP}_{\mathrm{i}}+\mathrm{KNPP}_{\mathrm{i}}$

dimana:

$\mathrm{KTP}_{\mathrm{i}}=$ konsumsi total rumahtangga petani padi (rupiah/tahun)

Selanjutnya perilaku petani padi dalam memutuskan pengeluaran investasi pendidikan, rekreasi dan menabung dinyatakan dalam persamaan struktural sebagai berikut:

$\mathrm{IEP}_{\mathrm{i}}=\mathrm{h}_{0}+\mathrm{h}_{1} \mathrm{PTP}_{\mathrm{i}}+\mathrm{h}_{2} \mathrm{JASP}_{\mathrm{i}}+\mathrm{h}_{3} \mathrm{KPP}_{\mathrm{i}}+\mathrm{U}_{8 \mathrm{i}}$

IUP $_{\mathrm{i}}=\mathrm{i}_{0}+\mathrm{i}_{1} \mathrm{PTP}_{\mathrm{i}}+\mathrm{i}_{2} \mathrm{LP}_{\mathrm{i}}+\mathrm{i}_{3} \mathrm{IEP}_{\mathrm{i}}+\mathrm{U}_{9 \mathrm{i}}$

$\mathrm{KRP}_{\mathrm{i}}=\mathrm{j}_{0}+\mathrm{j}_{1} \mathrm{PTP}_{\mathrm{i}}+\mathrm{j}_{2} \mathrm{KPP}_{\mathrm{i}}+\mathrm{j}_{3} \mathrm{IEP}_{\mathrm{i}}+\mathrm{j}_{4} \mathrm{KK}_{\mathrm{i}}+\mathrm{j}_{5} \mathrm{TABP}+\mathrm{U}_{10 \mathrm{i}}$

$\mathrm{TABP}_{\mathrm{i}}=\mathrm{k}_{0}+\mathrm{k}_{1} \mathrm{PTP}_{\mathrm{i}}+\mathrm{k}_{2} \mathrm{KPP}_{\mathrm{i}}+\mathrm{k}_{3} \mathrm{KNPP}_{\mathrm{i}}+\mathrm{k}_{4} \mathrm{KK}_{\mathrm{i}}+\mathrm{k}_{5} \mathrm{IEP}_{\mathrm{i}}+\mathrm{U}_{11 \mathrm{i}}$

dimana: 
$\mathrm{JASP}_{\mathrm{i}}=$ jumlah anak sekolah rumahtangga petani padi (orang)

$\mathrm{IUP}_{\mathrm{i}} \quad=$ investasi usaha rumahtangga petani padi (rupiah/tahun)

$\mathrm{KRP}_{\mathrm{i}} \quad=$ pengeluaran rekreasi rumahtangga petani padi (rupiah/tahun)

$\mathrm{TABP}_{\mathrm{i}}=$ jumlah tabungan rumahtangga petani padi (rupiah/tahun)

Tanda parameter dugaan yang diharapkan:

$\mathrm{h}_{1}, \mathrm{~h}_{2}, \mathrm{i}_{1}, \mathrm{i}_{2}, \mathrm{j}_{1}, \mathrm{k}_{1}>0$ dan $\mathrm{h}_{3}, \mathrm{i}_{3}, \mathrm{j}_{2}, \mathrm{j}_{3}, \mathrm{j}_{4}, \mathrm{j}_{5}, \mathrm{k}_{2}, \mathrm{k}_{3}, \mathrm{k}_{4}, \mathrm{k}_{5}<0$

Prosedur kedua adalah identifikasi model. Identifikasi model perlu dilakukan untuk menentukan metode estimasi model. Rumus identifikasi model berdasarkan order condition adalah sebagai berikut:

dimana:

$$
(\mathrm{K}-\mathrm{M}) \geq(\mathrm{G}-1)
$$

$\mathrm{K}=$ total peubah dalam model (peubah endogen dan peubah predeterminan)

$\mathrm{M}=$ jumlah peubah endogen dan eksogen yang dimasukkan ke dalam suatu persamaan tertentu dalam model

$\mathrm{G}=$ total persamaan (jumlah peubah endogen).

Kriteria identifikasi model dengan menggunakan order condition dinyatakan sebagai berikut: (1) jika $\mathrm{K}-\mathrm{M}=\mathrm{G}-1$, maka persamaan dalam model dinyatakan teridentifikasi secara tepat (exactly identified), (2) jika $\mathrm{K}-\mathrm{M}<\mathrm{G}-1$, maka persamaan dalam model dikatakan tidak teridentifikasi (unidentified), dan (3) jika K-M>G-1, maka persamaan dalam model dikatakan teridentifikasi berlebih (overidentified).

Berdasarkan hasil identifikasi, model ekonomi rumahtangga petani padi di Kabupaten Kampar dengan jumlah $\mathrm{K}$ adalah 28, M setiap persamaan paling banyak 5 dan $\mathrm{G}$ adalah 17. Dengan menghitung sesuai dengan persamaan 1 sehingga model tersebut teridentifikkasi berlebih (overidentified).

Prosedur analisis ketiga adalah mengestmasi model ekonomi rumahtangga petani padi sawah. Estimasi model tersebut menggunakan metode Two Stages Least Square (2SLS). Pendugaan nilai-nilai parameter dalam model dilakukan dengan memanfaatkan program komputer Statistical Analysis SystemEconometric Time Series (SAS-ETS).

HASIL DAN PEMBAHASAN

\section{Keragaan Umum Hasil Pendugaan Model Ekonomi Rumahtangga Petani Padi Sawah}

103 Kajian Ekonomi Rumahtangga Petani Padi Di Kabupaten Kampar Provinsi Riau 
Hasil pendugaan model ekonomi rumahtangga dalam penelitian ini cukup baik sebagaimana terlihat dari nilai koefisien determinasi $\left(\mathrm{R}^{2}\right)$ dari setiap persamaan. Nilai koefisien determinasi pada model ekonomi rumahtangga petani berkisar antara 0.54 sampai 0.90 . Nilai $\mathrm{R}^{2}$ yang terkecil (dibawah 0.60 ) terdapat pada persamaan investasi usahatani rumahtagga petani. Nilai $\mathrm{R}^{2}$ yang terkecil (dibawah 0.60) terdapat pada persamaan tersebut disebabkan karena jumlah sampel yang digunakan masih kecil. Namun demikian secara umum peubahpeubah eksogen yang dimasukkan pada setiap persamaan dalam model ekonomi rumahtangga petani mampu menjelaskan dengan baik peubah endogennya. Selain $\mathrm{R}^{2}$ sebagai ukuranuntuk menentukan suatu model dikatakan baik secara statistik, juga dilakukan uji F. Uji F perlu dilakukan untuk menunjukkan bahwa model tersebut baik pada setiap persamaan-persamaan. Nilai statistik uji F yang cukup tinggi (16.80 sampai 178.31) dan berbeda nyata pada taraf nyata 1 persen. Hal ini menunjukkan bahwa model keputusan ekonomi rumahtangga petani padi baik pada taraf nyata 1 persen.

Untuk menguji apakah masing-masing peubah eksogen berbeda nyata dengan nol terhadap peubah endogennya digunakan Statistik uji t. Dalam studi ini, taraf nyata yang digunakan sampai pada batas toleransi 30 persen. Dengan kata lain, taraf nyata di atas 30 persen dinyatakan tidak berbeda nyata dengan nol.

\section{Faktor-Faktor yang Mempengaruhi Ekonomi Rumahtangga Petani Padi Sawah}

Ekonomi rumahtangga petani padi meliputi aktivitas produksi dan konsumsi yang dilakukan oleh rumahtangga petani padi secara simultan. Dalam berproduksi rumahtangga petani padi mengalokasikan waktunya di dalam usahatani padi, sehingga mengahasilkan pendapatan di dalam usahatani padi. Selain itu, rumahtangga petani padi mengalokasikan waktunya untuk diluar usahatani padi untuk memperoleh pendapatan di luar usahatani. Dengan demikian pendapatan rumahtangga petani padi didukung oleh pendapatan di dalam dan di luar usahatani padi. Pendapatan rumahtangga tersebut digunakan petani untuk memenuhi kebutuhan rumahtangga petani. Kebutuhan tesebut terdiri dar kebutuhan pangan, sandang, pendidikan, kesehatan dan rekreasi. Dari hal tersebut ekonomi rumahtangga petani pada penelitian ini terdiri 10 persamaan struktural yang telah diestimasi. 10 persamaan tersebut dapat disajikan pada Tabel 1.

104 Kajian Ekonomi Rumahtangga Petani Padi Di Kabupaten Kampar Provinsi Riau 
Tabel 1.Pendugaan Parameter dan Elastisitas Persamaan-Persamaan Struktural Ekonomi Rumahtangga Petani Padi di kabupaten Kampar

1. Persamaan Produksi padi

\begin{tabular}{|l|r|r|r|r|}
\hline \multicolumn{1}{|c|}{ Peubah } & Parameter Dugaan & \multicolumn{1}{c|}{ t-hitung } & \multicolumn{1}{c|}{ Prob $>|\mathrm{t}|$} & \multicolumn{1}{c|}{ Elastisitas } \\
\hline Intercept & -48.346 & -0.360 & 0.7217 & \\
\hline LP & $1,625.903$ & 6.590 & $<.0001$ & 0.58 \\
\hline TTKU & 4.347 & 2.850 & 0.0062 & 0.41 \\
\hline BSP & 0.000023 & 0.88 & 0.3836 & \\
\hline R-Square $=0.905 ;$ F-hitung $=178.31 ;$ Prob $>\mathrm{F}=<.0001 ;$ Durbin-Watson $=1.36$ \\
\hline
\end{tabular}

2. Persamaan Alokasi waktu kerja petani padi dalam usaha tani

\begin{tabular}{|l|r|r|r|r|}
\hline \multicolumn{1}{|c|}{ Peubah } & Parameter Dugaan & t-hitung & Prob $>|\mathrm{t}|$ & \multicolumn{1}{c|}{ Elastisitas } \\
\hline Intercept & 68.309 & 6.630 & $<.0001$ & 0.38 \\
\hline PPDU & 0.000010 & 11.990 & $<.0001$ & 0.12 \\
\hline AKP & 6.437 & 1.870 & 0.0673 & r \\
\hline R-Square $=0.7721 ;$ F-hitung $=73.68 ;$ Prob $>\mathrm{F}=<.0001 ;$ Durbin-Watson $=1.71$ \\
\hline
\end{tabular}

3. Persamaan penggunaan tenaga kerja luar rumahtangga petani

\begin{tabular}{|l|r|r|r|r|}
\hline \multicolumn{1}{|c|}{ Peubah } & Parameter Dugaan & \multicolumn{1}{c|}{ t-hitung } & Prob $>|\mathrm{t}|$ & \multicolumn{1}{c|}{ Elastisitas } \\
\hline Intercept & -12.8742 & -3.2300 & 0.0021 & 1.02 \\
\hline PPDU & 0.0000016 & 6.9800 & $<.0001$ & 0.63 \\
\hline PKP & 0.2251 & 3.6600 & 0.0006 & 0.93 \\
\hline AKP & 2.9465 & 2.8000 & 0.007 & \\
\hline
\end{tabular}

R-Square $=0.505 ;$ F-hitung $=19.08 ;$ Prob $>F=<.0001 ;$ Durbin-Watson $=1.94$

4. Persamaan alokasi waktu kerja rumahtangga diluar usahatani

\begin{tabular}{|l|r|r|r|r|}
\hline \multicolumn{1}{|c|}{ Peubah } & Parameter Dugaan & t-hitung & Prob $>|\mathrm{t}|$ & \multicolumn{1}{c|}{ Elastisitas } \\
\hline Intercept & 82.786 & 3.930 & 0.0002 & \\
\hline PPLU & 0.000006 & 5.040 & $<.0001$ & 0.45 \\
\hline AKP & 29.98415 & 2.760 & 0.0077 & 0.26 \\
\hline
\end{tabular}

R-Square $=0.661 ;$ F-hitung $=55.69 ;$ Prob $>F=<.0001 ;$ Durbin-Watson $=2.06$

5. Persamaan Pendapatan Rumahtangga petani padi diluar usahatani

\begin{tabular}{|l|r|r|r|r|}
\hline \multicolumn{1}{|c|}{ Peubah } & Parameter Dugaan & \multicolumn{1}{c|}{ t-hitung } & Prob $>|\mathrm{t}|$ & \multicolumn{1}{|c|}{ Elastisitas } \\
\hline Intercept & 3145772 & 0.430 & 0.672 & \\
\hline CKPL & 86889.34 & 8.610 & $<.0001$ & 1.24 \\
\hline CKPD & -18946.9 & -1.200 & 0.2367 & -0.26 \\
\hline UP & -102154 & -1.290 & 0.2006 & \\
\hline R & &
\end{tabular}

R-Square $=0.688 ;$ F-hitung $=41.30 ;$ Prob $>F=<.0001 ;$ Durbin-Watson $=2.07$

6. Persamaan pengeluaran konsumsi pangan rumahtangga petani padi

\begin{tabular}{|l|r|r|r|r|}
\hline \multicolumn{1}{|c|}{ Peubah } & Parameter Dugaan & t-hitung & Prob $>|\mathrm{t}|$ & \multicolumn{1}{c|}{ Elastisitas } \\
\hline Intercept & 219395.2 & 0.110 & 0.9164 & 0.70 \\
\hline PTP & 0.395082 & 2.950 & 0.0047 & 0.37 \\
\hline JANP & 1694567 & 3.790 & 0.0004 & -0.08 \\
\hline IEP & -0.42313 & -1.840 & 0.0704 & \\
\hline
\end{tabular}

R-Square $=0.696 ;$ F-hitung $=42.80 ;$ Prob $>F=<.0001 ;$ Durbin-Watson $=2.01$

7. Investasi pendidikan rumahtangga petani padi

105 Kajian Ekonomi Rumahtangga Petani Padi Di Kabupaten Kampar Provinsi Riau 


\begin{tabular}{|l|r|r|r|r|}
\hline \multicolumn{1}{|c|}{ Peubah } & Parameter Dugaan & t-hitung & Prob $>|\mathrm{t}|$ & \multicolumn{1}{c|}{ Elastisitas } \\
\hline Intercept & -1307047 & -0.71 & 0.4811 & 4.41 \\
\hline PTP & 0.497079 & 4.61 & $<.0001$ & 0.56 \\
\hline JASP & 1863585 & 3.34 & 0.0015 & -3.52 \\
\hline KPP & -0.70397 & -3.77 & 0.0004 & \\
\hline R & &
\end{tabular}

R-Square $=0.563 ;$ F-hitung $=24.07 ;$ Prob $>F=<.0001 ;$ Durbin-Watson $=1.93$

8. Investasi usahatani

\begin{tabular}{|l|r|r|r|r|}
\hline \multicolumn{1}{|c|}{ Peubah } & Parameter Dugaan & \multicolumn{1}{c|}{ t-hitung } & Prob $>|\mathrm{t}|$ & \multicolumn{1}{c|}{ Elastisitas } \\
\hline Intercept & 21716808 & 9.62 & $<.0001$ & 0.38 \\
\hline PTP & 0.546175 & 4.88 & $<.0001$ & 0.05 \\
\hline LP & 3077005 & 2.35 & 0.0222 & \\
\hline IEP & -0.32676 & -1.26 & 0.2126 & \\
\hline R-Square $=0.540 ;$ F-hitung $=21.96 ;$ Prob $>\mathrm{F}=<.0001 ;$ Durbin-Watson $=2.38$ \\
\hline
\end{tabular}

9. Persamaan pengeluaran rumahtangga petani

\begin{tabular}{|l|r|r|r|r|}
\hline \multicolumn{1}{|c|}{ Peubah } & Parameter Dugaan & \multicolumn{1}{c|}{ t-hitung } & \multicolumn{1}{c|}{ Prob $>|\mathrm{t}|$} & \multicolumn{1}{c|}{ Elastisitas } \\
\hline Intercept & -782879 & -3.11 & 0.003 & 43.22 \\
\hline PTP & 0.72646 & 4.97 & $<.0001$ & -25.89 \\
\hline KPP & -0.77261 & -4.84 & $<.0001$ & -4.88 \\
\hline IEP & -0.72885 & -4.92 & $<.0001$ & -2.02 \\
\hline KK & -0.88599 & -3.71 & 0.0005 & -7.61 \\
\hline TABP & -0.66459 & -3.65 & 0.0006 & r \\
\hline R-Square $=0.869 ;$ F-hitung $=71.81 ;$ Prob $>\mathrm{F}=<.0001 ;$ Durbin-Watson $=1.98$
\end{tabular}

10. Persamaan tabungan rumahtangga petani padi

\begin{tabular}{|c|c|c|c|c|}
\hline Peubah & Parameter Dugaan & t-hitung & Prob $>|t|$ & Elastisitas \\
\hline Intercept & 670971.4 & 1.05 & 0.2963 & \\
\hline PTP & 0.798508 & 17.34 & $<.0001$ & 4.15 \\
\hline KPP & -0.8085 & -13.32 & $<.0001$ & -2.37 \\
\hline KNPP & -0.9015 & -1.65 & 0.1052 & -0.36 \\
\hline KK & -0.4709 & -1.17 & 0.2476 & \\
\hline IEP & -0.79743 & -12.96 & $<.0001$ & -0.47 \\
\hline
\end{tabular}

Tabel 1. Dapat dijelaskan bahwa luas panen dan total tenaga kerja dalam usahatani perpengaruh positif terhadap produksi padi dan signifikan pada taraf nyata 1 dan 5 persen. Hal ini mengindikasikan apabila luas panen dan total tenaga kerja dalam usahatani ditingkatkan maka produksi padi meningkat. Sedangkan biaya sarana produksi tidak responsif terhadap produksi padi.

Nilai elastisitas luas panen dan total tenaga kerja dalam usaha masing masing sebesar 0.58 dan 0.41. nilai elastisitas luas panen dan total tenaga kerja dalam usahatani tidak responsif, hal ini bermakna perubahan terhadap luas panen

106 Kajian Ekonomi Rumahtangga Petani Padi Di Kabupaten Kampar Provinsi Riau 
dan total tenaga kerja dalam usaha tidak berdampak besar terhadap perubahan produksi.

Berdasarkan tabel 2 dinyatakan bahwa pendapatan petani dalam usaha dan angkatan kerja petani berpengaruh positif terhadap alokasi waktu kerja petani padi dalam usahatani hal ini menunjukkan peningkatan pendapatan petani dalam usahatani dan angkatan kerja petani akan meningkatkan alokasi waktu kerja petani padi dalam usahatani.

Nilai elastisitas pendapatan petani padi dalam usahatani sebesar 0.38 sedangkan elastisitas angkatan kerja petani 0.12. hal ini bermakna bahwa perubahan pendapatan petani padi dalam usaha tani dan angkatan kerja petani akan berdampak kecil terhadap alokasi waktu kerja petani dalam usaha tani.

Tabel 3 dapat dijelaskan bahwa pendapatan petani dalam usahatani berpengaruh positif dan signifikan terhadap penggunaan tenaga kerja luar usahatani padi. Sedangkan pengalaman kerja petani dan angkatan kerja petani perpengaruh positif walau tidak signifikan.

Nilai elastisitas pendapatan petani dalam usahatani, pengalaman kerja petani dan angkatan kerja petani masing-masing 1.02, 0.63 dan 0.93. bermakna apabila pendapatan petani dalam usahatani meningkat sebesar 1 persen terjadi peningkatan penggunaan tenaga kerja luar rumahtangga petani sebesar 1.20 persen, pengalaman kerja petani dan angkatan kerja petani ditingkatkan 1 persen maka penggunaan tenaga kerja luar rumahtangga petani meningkat masing masing sebesar 0.63 dan 0.93 persen.

Tabel 4 menjelaskan bahwa pendapatan petani diluar usahatani dan angkatan kerja petani berpengaruh positif terhadap alokasi waktu kerja rumahtangga diluar usahatani padi namun tidak signifikan.

Nilai elastisitas pendapatan petani diluar usahatani dan angkatan kerja petani adalah 0.45 dan 0.26 . kondisi seperti ini menjelaskan bahwa apabila pendapatan petani diluar usahatani meningkat sebesar 10 persen dan angkatan kerja petani meningkat juga 10 persen maka alokasi waktu kerja diluar usaha tani padi ditingkatkan masing-masing sebesar 4.5 persen dan 2.6 persen.

Tabel 5. Dapat dijelaskan bahwa pendapatan rumah petani padi diluar usahatani dipengaruhi oleh curahan kerja petani padi diluar usahatani, curahan kerja petani dalam usahatani dan umur petani.umur petani berpengaruh negarif

107 Kajian Ekonomi Rumahtangga Petani Padi Di Kabupaten Kampar Provinsi Riau 
terhadap pendapatan rumahtangga petani padi diluar usahatani. Curahan kerja petani diluar usahatani signifikan pengaruhnya terhadap pendapatan rumahtangga petani diluar usahatani. Sedangkan curahan kerja petani dalam usahatani pengaruhnya tidak signifikan terhadap pendapatan petani diluar usahatani.

Nilai elastisitas curahan kerja petani diluar usahatani dan umur petani masing - masing adalah 1.24 dan -0.26. artinya jika curahan kerja petani di luar usaha tani ditingkatkan sebanyak 1 persen maka pendapatan rumahtangga petani padi diluar usahatani meningkat sebesar 1.24 persen. Sebaliknya umur petani berpengaruh negatif terhadap pendapatan petani diluar usaha tani. Semakin tinggi umur petani maka semakin sedikit curahan kerjanya kepada usahatani sehingga pendapatan petani semakin berkurang.

Tabel 6. Menunjukkan bahwa pengeluaran konsumsi pangan petani dipengaruhi oleh pendapatan total petani, jumlah anggota keluarga petani dan investasi pendidikan . pendapatan total petani dan jumlah anggota keluarga petani berpengaruh positif terhadap pengeluaran tetapi tidak signifikan sedangkan investasi pendidikan petani perpengaruh negarif. Hal ini menunjukkan bahwa jika investasi pendidikan ditingkatkan maka pengeluaran konsumsi pangan petani menurun. Semangkin meningkat pendidikan seseorang maka pengetahuannya semakin luas dan mempunyai pemikiran jauh kedepan. Sehingga dengan meningkatnya investasi pendidikan seseorang menyebabkan akan memanfaatkan pendapatannya untuk konsumsi non pangan, investasi pendidikan dan lainnya. Ketika jumlah anggota keluarga meningkat maka konsumsi pangan rumahtangga juga meningkat.

Nilai elastisitas konsumsi pangan rumahtangga petani padi terhadap pendapatan total petani padi, jumlah anggota keluarga petani dan investasi pendidikan masing-masing adalah $0.70,0,37$ dan -0.08 . berarti apabila pendapatan total petani padi meningkat sebesar 1 persen maka konsumsi pangan rumahtangga petani akan bertambah sebesar 0.38 persen. Apabila jumlah anggota keluarha bertambah 1 persen maka konsumsi pangan rumah tangga petani padi meningkat 0,37 persen. Demikian halnya dengan nilai elastisitas konsumsi pangan rumahtangga petani padi terhadap investasi pendidikan sebesar -0.04 berarti apabila investasi pendidikan meningkat sebesar 1 persen, maka konsumsi pangan rumahtangga petani akan menurun sebesar 0.08 persen.

108 Kajian Ekonomi Rumahtangga Petani Padi Di Kabupaten Kampar Provinsi Riau 
Tabel 7 menjelaskan tentang investasi pendidikan rumahtangga petani dipengaruhi oleh pendapatan total petani, jumlah anak sekolah dan konsumsi pangan petani. Pendapatan total petani berpengaruh positif dan signifikan terhadap investasi pendidikan artinya semakin tinggi pendapatan petani maka semakin meningkat investasi pendidikan . wawasan dan pengalaman petani lebih luas sehingga tingkat pendidikan anggota keluarga terutama anak akan semakin dipentingkan. Konsumsi pangan petani berpengaruh negatif terhadap pendidikan.

Nilai elastisitas dari masing masing peubah pendapatan total petani, jumlah anak sekolah dan konsumsi pangan petani adalah 4.41, 0.65 dan -3.52 . berarti apabila pendapatan total petani meningkat 1 persen maka investasi pendidikan bertambah sebanyak 4.41 persen, jumlah anak sekolah meningkat 1 persen maka investasi pendidikan meningkat sebanyak 0.65 persen. Namun bila konsumsi pangan petani meningkat 1 persen terjadi penurunan investasi pendidikan sebanyak 3.52 persen.

Tabel 8 menjelaskan bahwa pendapatan total petani dan luas panen berpengaruh positif terhadap investasi usahatani walau tidak signifikan. Nilai elastisitas pendapatan total petani lebih besar dibanding nilai elastisitas luas panen yaitu 0.38 dan 0.05 artinya jika pendapatan total petani meningkat 1 persen maka investasi usaha meningkat sebesar 0.38 persen sedangkan jika luas panen ditingkatkan sebesar 1 persen maka investasi usahatani meningkat hanya 0.05 persen.

Table 9 menunjukkan pendapatan total petani berpengaruh positif terhadap pengeluaran rekreasi dan sangat responsif. Ketika pendapatan total petani meningkat maka pengeluaran petani untuk rekreasi semakin banyak.Sedangkan konsumsi pangan petani, investasi pendidikan, pengeluaran kesehatan dan tabungan petani berpengaruh negatif terhadap pengeluaran rekreasi rumahtangga petani.

Nilai elastisitas pendapatan total petani terhadap pengeluaran rekreasi adalah 43.22 dan elastisitas konsumsi pangan petani, investasi pendidikan, pengeluaran kesehatan dan tabungan masing-masing adalah sebesar -25.89, -4.88, -2.02 dan -7.61. ketika konsumsi pangan petani meningkat 1 persen, pengeluaran rekreasi menurun sebesar 25.89 persen, investasi pendidikan naik sebesar 1 persen pengeluaran rekreasi menurun sebesar 4.88 persen, pengeluaran kesehatan 
meningkat 1 persen tabungan petani menurun 2.02 persen dan tabungan petani ditingkatkan 1 persen maka pengeluaran rekreasi menurun sebesar 7.61 persen.

Table 10 menerangkan bahwa tabungan rumahtangga petani dipengaruhi oleh pendapatan total petani, konsumsi pangan petani, konsumsi non pangan petani, pengeluaran kesehatan dan investasi pendidikan.

Pendapatan total rumahtangga petani padi dan suku bunga tabungan berpengaruh positif terhadap tabungan rumahtangga petani padi. Hal ini menunjukkan bahwa apabila pendapatan total rumahtangga petani padi dan suku bunga tabungan meningkat, maka jumlah tabungan rumahtangga petani padi akan bertambah. Untuk investasi pendidikan berpengaruh negatif terhadap tabungan rumahtangga petani padi yang menunjukkan bahwa apabila investasi pendidikan rumahtangga petani meningkat, maka tabungan rumahtangga petani akan berkurang.

\section{Kesimpulan}

\section{KESIMPULAN DAN IMPLIKASI KEBIJAKAN}

Berdasarkan pembahasan yang telah diuraikan pada bab terdahulu dan mengacu pada tujuan penelitian maka dapat dirumuskan kesimpulan sebagai berikut:

1. Produksi gabah positif dan signifikan dipengaruhi oleh faktor internal dan eksternal. Faktor internal seperti luas panen Sedangkan faktor eksternal seperti penggunaan tenaga kerja dalam keluarga.

2. Alokasi waktu kerja dalam keluarga petani signifikan dipengaruhi oleh faktor pendapatan petani dalam usaha dan angkatan kerja petani

3. Penggunaan tenaga kerja luar keluarga petani signifikan dipengaruhi oleh faktor internal rumahtangga petani padi, seperti pendapatan petani dalam usaha tani dan pengalaman kerja petani dan angkatan kerja petani

4. Alokasi waktu kerja luar usahatani dipengaruhi oleh faktor eksternal rumahtangga petani seperti pendapatan petani diluar usahatani dan faktor internal angkatan kerja petani.

5. Faktor internal yang signifikan mempengaruhi pendapatan luar usahatani adalah curahan kerja petani dalam usahatani umur petani dan curahan kerja petani di luar usahatani.

6. Faktor internal yang signifikan mempengaruhi pengeluaran pangan rumahtangga petani padi adalah pendapatan total rumahtangga petani , jumlah anggota keluarga petani.

110 Kajian Ekonomi Rumahtangga Petani Padi Di Kabupaten Kampar Provinsi Riau 
7. Investasi pendidikan signifikan dipengaruhi faktor internal seperti pendapatan total petani, pengeluaran konsumsi pangan dan jumlah anak sekolah.

8. Investasi usahatani signifikan dipengaruhi faktor internal seperti pendapatan total petani, dan luas panen.

9. Pengeluaran rekreasi signifikan dipengaruhi faktor internal seperti pendapatan total petani, pengeluaran non pangan dan konsumsi pangan petani.

10. Tabungan rumahtangga petani signifikan dipengaruhi faktor internal seperti pendapatan total petani, konsumsi pangan, konsumsi non pangan dan investasi pendidikan.

\section{Implikasi Kebijakan}

1. Peningkatan produksi padi sangat diperlukan dalam rangka mempertahankan ketahanan pangan beras nasional. Oleh karena itu pemerintah daerah perlu menetapkan harga input dan output serta memperbaiki irigasi, karena irigasi sangat penting untuk peningkatan produksi padi.

2. Pendidikan petani pada umum tergolong rendah dan pendidikan petani mempengaruhi petani dalam keputusan produksi dan menetukan pengeluaran rumahtangga petani. Oleh karena itu perlu pendidikan informal bagi petani berupa pelatihan dan pendampingan dalam rangka meningkatkan pendapatan petani.

3. Pendapatan rumahtangga petani sebagian besar terdiri dari pendapatan dalan usahatani padi dan signifikan mempengaruhi pengeluaran rumahtangga petani. Oleh karena itu perlu peran pemerintah dalam menetukan harga gabah yang stabil yang dapat mendorong petani untuk terus berproduksi.

\section{DAFTAR PUSTAKA}

Barnum, H.N. and L. Squire. 1978. An Econometric Application of the Theory of the Farm-Household. Journal of Development Economics, (6): 79-102.

Becker, G.S. 1965. A Theory of Allocation of Time. Economic Journal, 299 (75): 493-517.

Elinur. 2004. Analisisis Sosial Ekonomi Rumahtangga Industri Produk Jadi Rotan

111 Kajian Ekonomi Rumahtangga Petani Padi Di Kabupaten Kampar Provinsi Riau 
di Kota Pekanbaru. Tesis Magister Sains.Program Pascasarjana, Institut Pertanian Bogor. (Tidak Dipublikasi).

Elinur dan Asrol. 2015. Prilaku Ekonomi Rumahtangga Petani Kelapa Sawit di Desa Indra Sakti Kecamatan Tapung Kabupaten Kampar. Dalam Prosiding Seminar Nasional: Krtalisasi Paradigma Agribisnis dalam Pembangunan Ekonomi dan Pendidikan Tinggi. Departemen Agribisnis Fakultas Ekonomi dan Manajemen. Institut Pertanian Bogor, Bogor.

Faradesi, E. 2004. Dampak Pasar Bebas Terhadap Prilaku Ekonomi Rumahtangga Petani Padi di Kabupaten Cianjur: Suatu Analisis Simulasi Model Ekonomi Rumahtangga Pertanian. Tesis Sekolah Pascasarjana Institut Pertanian Bogor. (Tidak Dipublikasi).

Husin, L dan Dwi Wulan, S. 2011. Prilaku Ekonomi Rumahtangga Petani Karet di Pramubulih dalam Alokasi Tenaga Kerja, Produksi dan Konsumsi. Laporan Penelitian bekerjasama dengan Program Managing Higher Education For Relevance and Efficiency (I-MHERE).

Nakajima, C. 1989. ubjective Equilibrium Theory of The Farm Household. Elsevier Science Publisher. Amsterdam.

Rochaeni, S dan Erna M, L. 2005. Faktor-Faktor yang Mempengaruhi Keputusan Ekonomi Rumahtangga Petani di Kelurahan Setugede Kota Bogor. Jurnal Agro Ekonomi, 23(2): 133-156.

Singh, I., L. Squire and J. Strauss. 1986. Agricultural Household Models: Extension, Application and Policy. The John Hopkins University Press, Baltimore. 